\title{
GLYCINE-C-14 INCORPORATION INTO NUCLEIC ACID PURINE BY LEUCOCYTES OBTAINED FROM NORMAL AND GOUTY SUBJECTS*
}

\author{
BY \\ HERBERT S. DIAMOND,$\dagger$ MICHAEL FRIEDLAND $\ddagger$ \\ DAVID HALBERSTAM, AND DAVID KAPLAN \\ From the College of Medicine, State University of New York, Downstate Medical Center Brooklyn, and \\ Kings County Hospital Center, New York
}

Attempts to characterize the biochemical defect or defects responsible for overproduction of uric acid in primary gout have been hampered by the lack of a suitable experimental model and the necessary limitations of research in vivo in man.

The purpose of the present study was to investigate metabolic abnormalities in purine metabolism in vitro using an intact human cell system. Leucocytes were chosen for study because of the ease with which they can be obtained and their relative resistance to non-physiological conditions (Fallon, Frei, Davidson, Trier, and Burk, 1962).

The rate of incorporation of C-14 tagged purine precursors into nucleic acid adenine and guanine by isolated human leucocytes was measured in leucocytes obtained from hyperuricaemic subjects and normouricaemic controls. Increased incorporation of glycine C-14 by white cells from hyperuricaemic subjects was found.

\section{Material and Methods}

Uniformly labelled glycine-C-14 was used.** Phosphate buffer (Munroe and Shipp, 1965) pH 7.4 was prepared by diluting $10 \mathrm{ml}$. of Solution $\mathrm{A}(75.0 \mathrm{~g} . \mathrm{NaCl}$, $7 \cdot 5$ g. KCl, $1 \cdot 0$ g. $\mathrm{Na}_{2} \mathrm{HPO}_{4}, 1 \cdot 7$ g. $\mathrm{KH}_{2} \mathrm{PO}_{4}$, and $0 \cdot 5$ g. $\mathrm{K}_{2} \mathrm{HPO}_{4}$ per litre) and $7 \mathrm{ml}$. of Solution B (10.0 g. $\mathrm{NA}_{2} \mathrm{HPO}_{4}$ per litre) to $100 \mathrm{ml}$. with water.

Pertinent clinical features of leucocyte donors are shown in Table I (see p. 277). All medications were discontinued 72 hours before blood was drawn. Subjects with blood urea nitrogen above $20 \mathrm{mg}$. per cent. or other evidence of impaired renal function were excluded. No patients with secondary hyperuricaemia were studied. All donors were ambulatory and not ill at the time blood was drawn. Uric acid was measured by the uricase method (Praetorius, 1949). Normouricaemic donors had

*Presented in part at the meeting of the American Rheumatism Association in Cincinnati, December, 1966.

†United States Public Health Service Trainee in Arthritis under Training Grant T1-AM-5365.

$\ddagger$ Medical Student, Summer Fellow of the New York Chapter of the Arthritis Foundation.

§John and Mary R. Markle Scholar in Academic Medicine, Senior Investigator, Arthritis Foundation.

* Specific activity 50 to $80 \mathrm{mc}$. $/ \mathrm{m}$. mole, obtained from Schwarz Bio. Research Inc. uric acid levels below $6.5 \mathrm{mg}$. per cent. Hyperuricaemic donors had uric acid levels above $7 \mathrm{mg}$. per cent. and a history of gouty arthritis. All but one subject in each group were adult males.

Viability and metabolic activity of leucocytes isolated by dextran sedimentation techniques have been demonstrated (Fallon and others, 1962). Viability was confirmed by their normal morphological appearance, motility, and staining characteristics with Trypan blue before and after incubation, and by the demonstration of linear incorporation rates of glycine-C-14 during 4-hour incubations (Figure).

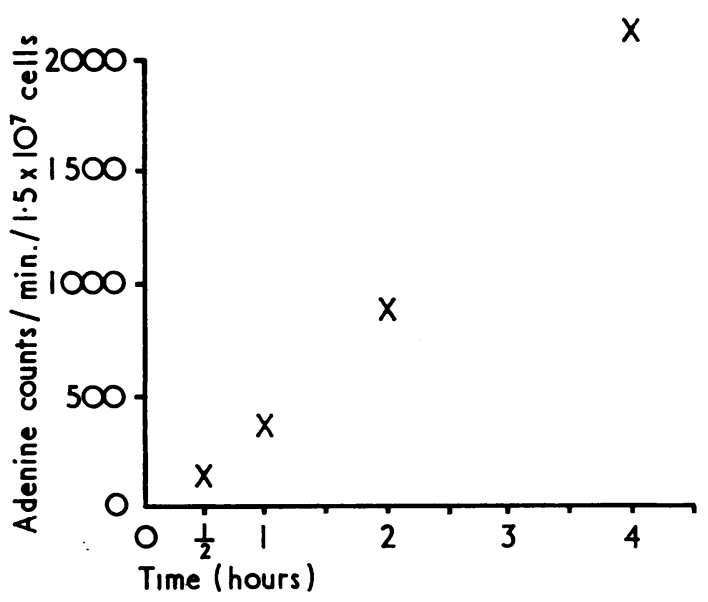

Figure.-Incorporation rates of glycine-C-14.

\section{Separation of Leucocytes}

All glassware was siliconized, rinsed, and freed of pyrogens. Leucocytes were separated from $50 \mathrm{ml}$. blood which had been drawn into a syringe pre-wetted with heparin. A technique similar to that of Munroe and Shipp (1965) was employed. The $50 \mathrm{ml}$. blood were immediately added to $12.5 \mathrm{ml} .0 .85$ per cent. $\mathrm{NaCl}$ containing 5 per cent. dextran, ${ }^{*}$ in a $100 \mathrm{ml}$. graduated

\footnotetext{
*Molecular weight 227,000 .
} 
cylinder, mixed, and allowed to sediment for $\mathbf{4 0}$ to $\mathbf{5 0}$ minutes at $4^{\circ} \mathrm{C}$. The supernatant was removed and centrifuged at $50 \mathrm{G}$. for 15 minutes at $4^{\circ} \mathrm{C}$. The supernatant was discarded and the cell pellet resuspended in $5 \mathrm{ml}$. phosphate buffer. Twice the volume of distilled water was added and the suspension was centrifuged as before. The cell pellet was resuspended in $2 \mathrm{ml}$. phosphate buffer and quadruplicate cell counts were done. The volume was adjusted to give a final white blood cell concentration of $15 \times 10^{6}$ cells per ml. Differential counts following separation were in the normal range.

\section{Incubation of Leucocytes}

$2 \mathrm{ml}$. aliquots of the white blood cell suspension were diluted with $1 \mathrm{ml}$. incubation solution. The latter consisted of phosphate buffer (pH 7.4) containing 6.6 $\mathrm{mg}$. glucose per $\mathrm{ml}$. and the carbon-14 containing substrate. The cell suspensions were oxygenated by gently bubbling 100 per cent. oxygen through them for 15 seconds. Samples were incubated at $37^{\circ} \mathrm{C}$. for 4 hours while being gently mixed with a tissue culture rotator.

\section{Isolation of Adenine and Guanine}

Nucleic acids were isolated and hydrolysed by a modification of the technique described by Cooper and Rubin (1965). At the end of the 4-hour incubation, the reaction was stopped by cooling to $4^{\circ} \mathrm{C}$. in an ice-water bath and the cells separated by centrifugation at $600 \mathrm{G}$. for 10 minutes. Cells were washed once with cold phosphate buffer and fixed with cold ethyl alcoholacetic acid fixative $(3: 1)$ for 10 minutes. The cells were recovered by centrifugation and the cell pellet stored overnight in 70 per cent. ethanol at $4^{\circ} \mathrm{C}$. The following day the cells were extracted with 2 per cent. perchloric acid for 50 minutes at $4^{\circ} \mathrm{C}$. The supernatant was discarded, and the cells were washed once with 2 per cent. perchloric acid and then extracted with $0.5 \mathrm{ml} .10$ per cent. perchloric acid for 3 hours at $65^{\circ} \mathrm{C}$. The suspension was centrifuged and $0.4 \mathrm{ml}$. of the supernatant was removed, diluted with an equal volume of 70 per cent. perchloric acid, and heated in a boiling-water bath for 2 hours. The solution was de-salted by neutralization with concentrated potassium hydroxide, the precipitate was discarded, and the clear supernatant saved. Duplicate $0.1 \mathrm{ml}$. aliquots were spotted on Whatman No. 1 chromatography paper. Adenine and guanine were separated by descending paper chromatography, using an isopropyl alcohol-hydrochloric acid-water media (130: 33:37) (Thomson, 1960); the spots were located by ultraviolet light, cut out, and eluted, and the radioactivity of the elutate was determined in a Packard Tri-Carb liquid scintillation counter. The counting solution consisted of $17 \mathrm{ml}$. liquiflor solution* diluted with scintillation grade toluene, alkalinized with $0.5 \mathrm{ml}$. NCS solubilizer.* Radioactivity counts were expressed per $3 \times 10^{7}$ cells per minute.

\footnotetext{
*Nuclear Chicago.
}

\section{Intracellular Glycine}

Leucocytes were separated from 30 to $50 \mathrm{ml}$. of whole blood by collection in 5 per cent. sodium EDTA and lysis of the erythrocytes with dilute ammonium chloride (Di'oguardi, Agostoni, Fiorelli, and Lomanto, 1963). The leucocrit was then estimated in a Wintrobe haematocrit tube, the leucocytes were taken up in distilled water, frozen and thawed several times to release the intracellular amino acids, and the suspension was chromatographed on a Technicon amino Autoanalyzer (Dickinson, Rosenblum, and Hamilton, 1965). Intracellular glycine was expressed as micromoles of glycine per $\mathrm{ml}$. packed leucocytes.

\section{Results}

The radioactive material isolated was identified by its identical migration with adenine and guanine in three different chromatographic solutions, isopropyl alcohol, hydrochloric acid and water (130: $33: 37)$, butanol and water $(172: 28)$, and water alone. Purity of the isolated material was assessed $\vec{\varnothing}$ by counting duplicate aliquots after one-way 6 chromatography and two-way chromatography using two of the above media. When mean glycine C-14 incorporation rates into adenine were 1,110 counts/min. $/ 3 \times 10^{7}$ cells using one-way chromatography, two-way chromatography resulted in $\frac{\circ}{D}$ 1,049 counts $/ \mathrm{min} . / 3 \times 10^{7}$ cells. Corresponding $\stackrel{\varrho}{\Rightarrow}$ data for guanine were 789 counts $/ \mathrm{min} . / 3 \times 10^{7}$ cells with one-way chromatography and 741 counts/ $\min . / 3 \times 10^{7}$ cells with two-way chromatography.

The incorporation of glycine into adenine and guanine by white blood cells from fifteen normouricaemic adults and from fifteen adults with primary hyperuricaemia is shown in Table I (opposite). All results are reported in counts $/ \mathrm{min} . / 3 \times 10^{7}$ cells. Mean incorporation rates into adenine $\left(1,702 \pm 222^{*}\right)$ by white blood cells from hyperuricaemic donors 음 were 1.8 times greater than by white blood cells of $D$ normouricaemics (adenine 1,019 $\pm 173^{*}$ ). Mean incorporation rates into guanine $\left(1,059 \pm 175^{*}\right)$ by white blood cells from hyperuricaemic donors were also 1.8 times greater than by white blood cells 0 of normouricaemics $\left(615 \pm 130^{*}\right)$. The differences $\mathrm{\omega}$ between normouricaemic and hyperuricaemic sub- $\mathcal{O}$ jects for adenine and the sum of adenine and guanineco are significant $(P<0.05)$ by the four-fold table $\Phi$ test. The differences for guanine were not signifi-? cant at the 5 per cent. level.

Intracellular glycine pools were measured for the $\frac{\overrightarrow{0}}{\bar{D}}$ leucocytes derived from gouty and normouricaemic $\frac{\rho}{\mathbb{Q}}$ subjects to determine whether the differential $\varrho$

\footnotetext{
*Standard error of the mean.
} 
TABLE I

GLYCINE-C-14 INCORPORATION INTO LEUCOCYTE NUCLEIC ACID

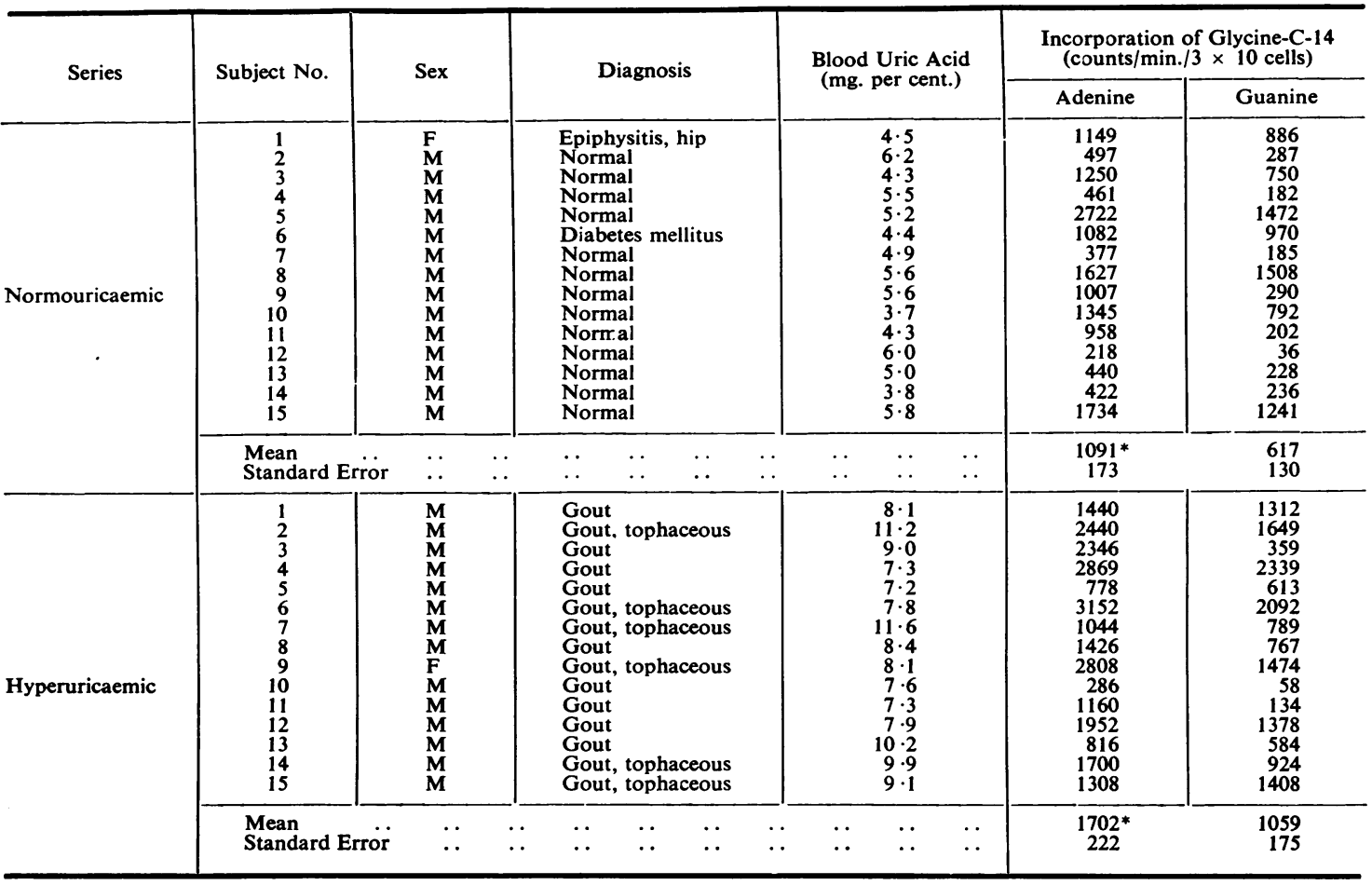

${ }^{*} \mathrm{P}<0.05$ (4-fold table test).

incorporation rates of glycine observed could result from differences in dilution of labelled glycine. Essentially no difference in glycine pool size was demonstrated in the two sets of white blood cells; the mean glycine pool in cells from six control subjects was $2.503 \mathrm{mM} / \mathrm{ml}$. packed white blood cells compared with $2.663 \mathrm{mM} / \mathrm{ml}$. packed white blood cells in the six hyperuricaemic subjects.

When anaerobic glycolysis was inhibited by adding $10^{-4}$ molar iodacetamide to the incubation media, mean incorporation of glycine into adenine decreased by 63 per cent. and mean incorporation into guanine decreased by 61 per cent. of control levels (Table II). A similar but less marked effect occurred when oxidative metabolism was inhibited by $3 \times 10^{7}$ molar cyanide. Incorporation of glycine into adenine decreased by 49 per cent. and into guanine by 48 per cent. (Table II). Metabolic inhibitors were equally effective on cells from normal and hyperuricaemic subjects.

White blood cells from hyperuricaemic and normouricaemic donors were incubated with $5 \mathrm{mc}$. hypoxanthine-8-C-14 in a manner similar to that described for glycine. Hypoxanthine was converted to adenine and guanine and incorporated into nucleic acids by the leucocytes from all 22 subjects

TABLE II

EFFECT OF METABOLIC INHIBITORS ON INCORPORATION OF $1 \mathrm{mc}$. GLYCINE-C-14

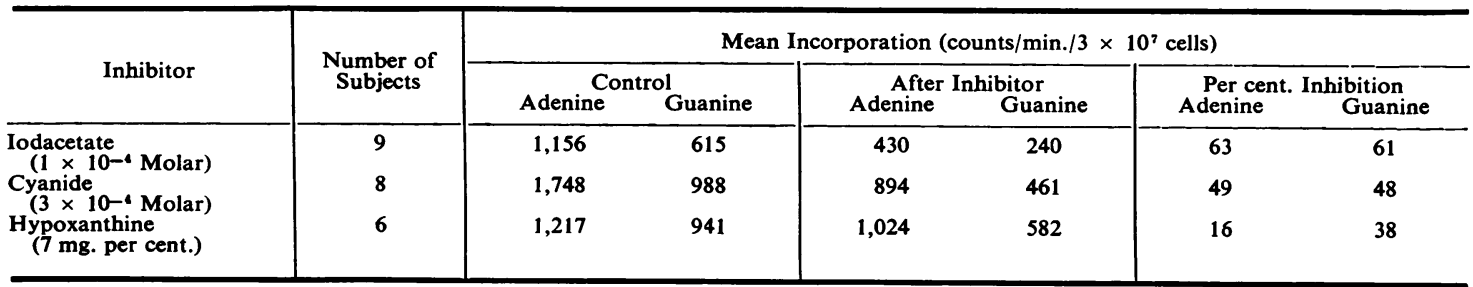


studied. Mean rates of incorporation of hypoxanthine in white blood cells from ten normouricaemic subjects, expressed as counts $/ \mathrm{min} . / 10^{7}$ cells, were 18,052 for adenine and 11,132 for guanine. Analogous incorporation rates by white blood cells from twelve hyperuricaemic subjects were essentially the same; 22,062 for adenine and 11,201 for guanine $(P>0.2)$. Similar incubations using $5 \mathrm{mc}$. xanthine8-C-14 have shown no incorporation in the leucocytes of all subjects studied.

The ability of hypoxanthine to inhibit glycine-C-14 incorporation into nucleic acid was studied by incubating duplicate aliquots of leucocytes one of which contained $7 \mathrm{mg}$. per cent. non-radioactive hypoxanthine, with $1 \mathrm{mc}$. glycine-C-14 (Table II). Mean rates of incorporation of glycine decreased by 16 per cent. for adenine and by 38 per cent. for guanine. This incorporation was inhibited equally in white blood cells from normouricaemic and gouty subjects.

\section{Discussion}

The linear increase in incorporation of glycine-C14 (Figure) indicates that the leucocytes were metabolically active and incorporating this substrate into purine throughout the 4-hour incubation period. Further evidence of their functional integrity is provided by the presence of pseudopod formation, amoeboid movements, and phagocytic activity both before and after incubation.

The marked decrease in rate of incorporation of glycine seen when anaerobic glycolysis was inhibited by iodacetamide and oxidative metabolism by cyanide suggests that the system studied is energydependent and that an intact glycolytic pathway is required for optimal incorporation of glycine into purine.

The material isolated from the leucocytes was identified as adenine and guanine on the basis of absorbance in ultraviolet light, $R f$ values typical of adenine and guanine in three chromatographic solutions (Thomson, 1960), and migration with added adenine and guanine in the same three solutions. The similar values for radioactivity obtained using one-way and two-way chromatography suggest that significant contaminating radioactivity was not present.

Although glycine C-14 was incorporated into adenine and guanine $1 \cdot 8$ times greater by leucocytes from hyperuricaemic than from normouricaemic subjects (Table I), the large overlap between the two groups of data suggests either a relatively minor quantitative abnormality, or that the hyperuricaemic subjects represented a heterogeneous group, only a portion of whom have leucocytes which overincorporate glycine. Since 24-hour urinary uric acid excretions by the subjects were not measured, one cannot know whether the subjects whose leucocytes overincorporated in this study are renal overexcretors.

The nature of the abnormality responsible for the observed difference in incorporation rates of this purine precursor is unknown. Free purine base, soluble ribonucleic acid (RNA), and desoxyribonucleic acid (DNA) can be extracted separately with different concentrations of perchloric acid (Ogur and Rosen, 1950). In the procedure used for the present study, acid-soluble RNA and any remaining free purine base are extracted in the 70 per cent. ethanol, ethanol-acetic acid, and 2 per cent. perchloric acid extractions (Feinendegen, Bond, and Painter, 1961). Thus, the method used measures only the adenine and guanine incorporated into DNA and the insoluble fraction of cellular RNA. Overincorporation of glycine by white blood cells from hyperuricaemic subjects in this assay system cannot result from excessive activity of a shunt pathway, since the overincorporation is into purine bases isolated from nucleic acid (Benedict, Yü, Bien, Gutman, and Stetten, 1953). Since the leucocyte glycine pool size was essentially the same in the normouricaemic and hyperuricaemic subjects, the differential incorporation rates of glycine observed cannot result from variations in the degree of dilution of isotopically-labelled glycine in the intracellular glycine pool.

Adenine and guanine are not metabolic endproducts of purine metabolism, and accordingly measuring their concentrations cannot give complete data on the state of purine metabolism. Glycine incorporation rates determined with the present technique do not necessarily reflect the overall rate of de novo purine biosynthesis. Abnormalities of purine metabolism involving pathways, such as the shunt pathway, which do not result in the incorporation of purine into insoluble RNA or DNA would not be detected.

The conversion of hypoxanthine-C-14 to adenine and guanine was expected, since at least two mechanisms for resynthesis of ribonucleotides from free purine bases including hypoxanthine are known to exist (Wyngaarden, 1966). This conversion probably represents an important source of ribonucleotides in some tissues (Abrams and Bentley, 1955). No difference was found in the rate of 
incorporation of hypoxanthine by leucocytes from hyperuricaemic and normouricaemic subjects. This suggests that the site at which the hyperuricaemics studied overincorporate purine is prior to the point where hypoxanthine is recycled into the pathway. Partial deficiency of the enzyme hypoxanthineguanine phosphoribosyl transferase reported to be found in some adult gouty subjects (Kelley, Rosenbloom, Henderson, and Seegmiller, 1967) was not demonstrated in any of the gouty subjects studied. The failure to detect incorporation of xanthine-C-14 into nucleic acid indicates that, at least by this leucocyte assay system, human white blood cells lack a significant salvage pathway for xanthine.

Unlabelled hypoxanthine was added to the incubation media to study its effect on de novo purine biosynthesis. Feedback inhibition of de novo purine biosynthesis is thought to result from inhibition of glutamine phosphoribosylpyrophosphate amidotransferase by adenylic and guanylic acid (Wyngaarden and Ashton, 1959; Henderson, 1962; Caskey, Ashton, and Wyngaarden, 1964). Hypoxanthine is probably converted to adenylic and guanylic acid in this system. The inhibition of glycine-C-14 incorporation produced by hypoxanthine in the leucocyte system probably results from increased cellular levels of these compounds. Inhibition was produced by hypoxanthine in the two gouty subjects studied, providing indirect evidence that feedback inhibition of de novo purine synthesis by adenylic and guanylic acid was not deranged in them. Such an abnormality has recently been described in some adult gouty subjects (Rosenbloom, Henderson, Kelley, and Seegmiller, 1968).

The demonstration of an abnormality in purine metabolism in white blood cells from adults with primary hyperuricaemia makes available a system for the further evaluation in vitro of the metabolic derangements characteristic of gout. This system could provide a valuable experimental model for attempts to delineate in vitro the biochemical defect or defects responsible for overproduction of uric acid in gout.

\section{Summary}

The incorporation of carbon-14 tagged purine precursors into adenine and guanine of insoluble RNA and DNA of human white blood cells was measured in vitro. Leucocytes from hyperuricaemic subjects incorporated 80 per cent. more glycine-C-14 into nucleic acid adenine and guanine than did leucocytes from normouricaemic controls. GlycineC-14 incorporation was inhibited by iodoacetamide, cyanide and hypoxanthine. Inhibition was equal in cells from hyperuricaemic and normouricaemic subjects. The potential value for future research of an in vitro system showing an abnormality of purine metabolism in hyperuricaemic subjects is emphasized.

\section{REFERENCES}

Abrams, R., and Bentley, M. (1955). Arch. Biochem. Biophys., 58, 109 (Biosynthesis of nucleic acid purine. II. Role of hypoxanthine and xanthine compounds).

Benedict, J. D., Yü, T. F., Bien, E. J., Gutman, A. B., and Stetten, DeW., Jr. (1953). J. clin. Invest., 32, 775 (Further study of the utilization of dietary glycine nitrogen for uric acid synthesis in gout).

Caskey, C. T., Ashton, D. M., and Wyngaarden, J. B. (1964). J. biol. Chem., 239, 2570 (The enzymology of feedback inhibition of glutamine phosphoribosylpyrophosphate amidotransferase by purine ribonucleotides).

Cooper, H. L., and Rubin, A. D. (1965). Blood, 25, 1014 (RNA metabolism in lymphocytes stimulated by phytohemagglutinin: Initial response to phytohemagglutinin).

Dickinson, J. C., Rosenblum, H., and Hamilton, P. B. (1965). Pediatrics, 36, 2 (Ion exchange chromatography of the free amino acids in the plasma of the newborn infant).

Di'oguardi, N., Agostoni, A., Fiorelli, G., and Lomanto, B. (1963). J. Lab. clin. Med., 61, 713 (Characterization of LDH of normal human granulocytes).

Fallon, H. J., Frei, E., Davidson, J. D., Trier, J. S., and Burk, D. (1962). Ibid., 59, 779 (Leukocyte preparations from human blood: evaluation of their morphologic and metabolic state).

Feinendegen, L. E., Bond, V. P., and Painter, R. B. (1961). Exp. Cell Res., 22, 381 (Studies on the interrelationship of RNA synthesis, DNA synthesis, and precursor pool in human tissue culture cells studied with tritiated pyrimidine nucleosides).

Henderson, J. F. (1962). J. biol. Chem., 237, 2631 (Feedback inhibition of purine biosynthesis in ascites tumor cells).

Kelley, W. N., Rosenbloom, F. M., Henderson, J. F., and Seegmiller, J. E. (1967). Proc. nat. Acad. Sci.(Wash.), 57, 1735 (A specific enzyme defect in gout associated with overproduction of uric acid).

Munroe, J. F., and Shipp, J. C. (1965). Diabetes, 14, 584 (Glucose metabolism in leucocytes from patients with diabetes mellitus with and without hypercholesterolemia). 
Ogur, M., and Rosen, G. (1950). Arch. Biochem, 25, 262 (The nucleic acids of plant tissues. I. The extraction and estimation of desoxypentose nucleic acid and pentose nucleic acid).

Praetorius, E. (1949). Scand. J. Lab. clin. Med., 1, 222 (Enzymatic method for determination of uric acid by ultraviolet spectrophotometry).

Rosenbloom, F. M., Henderson, J. F., Kelley, W. N., and Seegmiller, J. E. (1968). Arthr. and Rheum., 11, 507 (A defect of feedback inhibition in adult gout with overproduction of uric acid).

Thomson, R. Y. (1960). "Purines, pyrimidines and their derivatives", in "Chromatographic and Electrophoretic Techniques", ed. I. Smith, vol. 1, p. 237. Heinemann, London.

Wyngaarden, J. B. (1966). "Gout", in "The Metabolic Basis of Inherited Disease", ed. J. B. Stanbury, J. B. Wyngaarden, and D. S. Frederickson, 2nd ed., p. 667. McGraw-Hill, New York.

- and Ashton, D. M. (1959). J. biol. Chem., 234, 1492 (The regulation of activity of phosphoribosylpyrophosphate amidotransferase by purine ribonucleotides: a potential feedback control of purine biosynthesis).

L'incorporation de la glycine-C-14 à la purine de l'acide nucléique par les leucocytes obtenus de sujets sains et goutteux

\section{RÉSUMÉ}

L'incorporation des précurseurs de la purine contenant du carbon-14 à l'adénine et à la guanine des acides insolubles ribo-nucléique et déoxyribose-nucléique des globules blancs de l'homme a été mesurée in vitro. Les leucocytes des sujets hyperuricémiques avaient incorporé 80 pour cent. plus de glycine-C-14 dans l'adénine et la guanine de l'acide nucléique que ne l'avaient fait les leucocytes des témoins à acide urique sanguin normal. L'incorporation de la glycine-C-14 était inhibée par l'iodoacémide, le cyanure et l'hypoxanthine. L'inhibition était égale dans les cellules des sujets hyperuricémiques et celles des sujets à acide urique sanguin normal. La valeur pour des recherches ultérieures d'un système in vitro montrant une anomalie du metabolisme des purines chez des sujets hyperuricémiques est soulignée.
Incorporación de glicina-C-14 en purina de acido nucleico por leucocitos obtenidos de sujetos normales y gotosos

\section{SUMARIO}

La incorporación de precursores de purina, marcados por el carbón-14 en la adenina y la guanina del ARNy del ADN de glóbulos blancos humanos fue medida in vitro. Los leucocitos de sujetos hiperuricémicos incorporaron 80 por ciento más de glicina-C-14 en adenina y guanina de ácido nucleico que los leucocitos de testigos normouricémicos. La incorporación de glicina-C-14 fue inhibida por yodoacetamida, cianuro e hipoxantina. La inhibición fue igual en células de sujetos hiperuricémicos y normouricémicos. Se subraya el posible valor, para investigaciones futuras, de un sistema in vitro que muestra una anormalidad del metabolismo de la purina en sujetos hiperuricémicos. 